\title{
Investigations of the Compressive Behaviour of Veneer in Thickness Direction
}

\section{Istraživanje kompresijskih svojstava furnira u smjeru debljine}

\author{
Original scientific paper • Izvorni znanstveni rad \\ Received-prispjelo: 14. 7. 2011. \\ Accepted-prihvaćeno: 9. 2. 2012. \\ UDK: $630 * 812.72 ; 832.281$ \\ doi:10.5552/drind.2012.1122
}

\begin{abstract}
Compression tests were conducted with veneers in the thickness direction. Thereby differences between the stress-strain curves of veneers and other known stress-strain curves were observed. Based on microscopic studies during the compression, it was possible to describe the deformation behaviour of the veneer, and deviations from known, typical stress-strain curves were substantiated and explained. It was found that a considerable part of the strain occurs by straightening the veneer at a relatively low stress level due to the waved form of veneer sheets and specimens. A distinctive stress plateau has not been established.
\end{abstract}

Keywords: compression test, deformation, light microscope, stress-strain curve, veneer

SAŽETAK • Na furnirima su provedeni kompresijski testovi u smjeru njihove debljine. Uspoređene su dobivene krivulje naprezanja-deformacije furnira s drugim poznatim krivuljama naprezanja-deformacija. Na osnovi mikroskopske studije tijekom kompresije furnira moguće je opisati deformacije furnira i objasniti odstupanje od dosad poznatih, tipičnih krivulja naprezanja-deformacija. Istraživanja su pokazala da se zbog valovitosti listova furnira $i$ uzoraka velik dio deformacija pojavljuje pri ispravljanju furnira već uz relativno nisku razinu naprezanja.

\section{Ključne riječi: kompresijski test, svjetlosni mikroskop, krivulja naprezanja-deformacija, furnir}

\section{INTRODUCTION}

1. UVOD

During veneer coating of boards, veneers are exposed to compressive stress perpendicular to fibre direction. Thereby, the amount of compression depends on the used adhesive, i.e. the compression is determined by the producer of adhesives. In order to estimate the behaviour of veneers under pressure, compressive tests in thickness direction of veneers were conducted. Thereby, differences were observed of the stress-strain curves of veneers from other known stressstrain curves. Gibson and Ashby (1997) have described the compressive stress-strain curve for a number of wood species perpendicular to the fibre. They have described linear-elastic behaviour for very small strains, less than about $2 \%$. Beyond this area, the curve shows a stress plateau extending to strains between $10 \%$ and $80 \%$ depending on the density of the wood. For beech

\footnotetext{
${ }^{1}$ The authors are assistant and professor at Institute of Wood and Paper Technology, Technische Universität Dresden, Dresden, Germany. ${ }^{2}$ The author is professor at Faculty of Wood Science and Technology, Eberswalde University for Sustainable Development - University of Applied Sciences, Eberswalde, Germany.

Autori su asistentica i profesor Odjela za tehnologiju drva i papira Tehničkog sveučilišta u Dresdenu, Dresden, Njemačka. ${ }^{2}$ Autor je profesor Fakulteta za znanost o drvu i tehnologiju Sveučilišta primijenjenih znanosti, Eberswalde, Njemačka.
} 


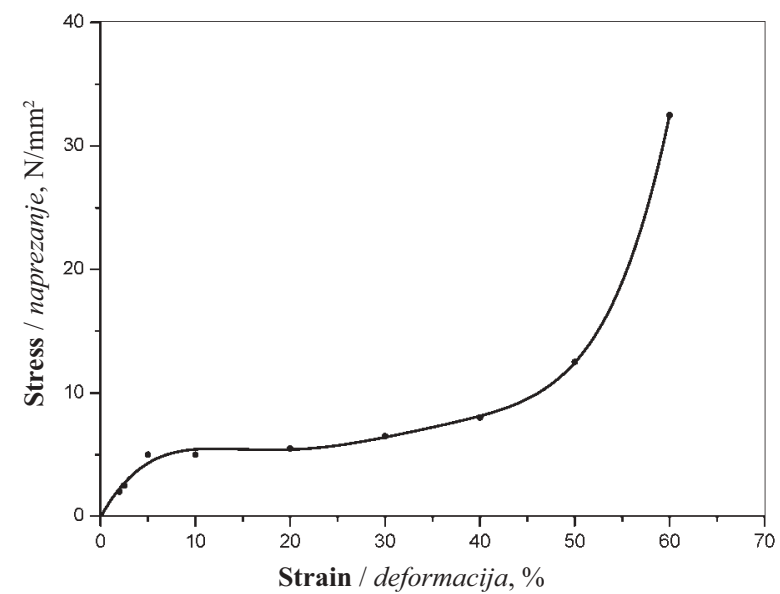

Figure 1 Typical stress-strain curve by compression for Aspen (Tabarsa and Chui, 2001)

Slika 1. Tipična krivulja naprezanja-deformacija za kompresiju drva jasike (Tabarsa i Chui, 2001)

they have displayed the beginning of the plateau at about $4 \%$. At the end of the plateau, the stress rises sharply (see Fig. 1). Ellis and Steiner (2002) have investigated the behaviour of five wood species in compression. All species have shown a more or less steep slope up to 2 to $3 \%$ strain in radial or tangential compression, followed by the stress plateau described by Gibson and Ashby (1997). Depending on species and density, the stress plateau reached $20 \%$ or $70 \%$ strain. Numerous other investigations have led to similar results (Dwianto et al, 1998; Shams and Yano, 2004; Tabarsa and Chui, 2001).

Compressive tests are often conducted in connection with a densification of wood. In general, such investigations aim at the production of wood with permanently higher density. In order to densify the wood as undamaged and high as possible, it is softened or plasticized. Thus, clearly higher compressive strains are reached. However, the general devolution of the stressstrain curves does not differ from the non-plasticized wood concerning the strain values of the elastic range. The stress plateau begins at approximately 2 to $5 \%$ (Inoue et al, 2008; Morsing, 2000).

This study presents and discusses the material behaviour of veneers under compressive stress in thickness direction. The aim of this study was the understanding of the material behaviour under pressure. Thereto stress-strain curves obtained from compressive tests of veneer are explained and differences between the stress-strain curves obtained for veneers and that described above are reasoned.

\section{MATERIALS AND METHODS}

\section{MATERIJALI I METODE}

Compressive tests were conducted with beech veneers (Fagus sylvatica L.) using a universal testing machine. Thereto commercially available veneers were used, produced for decorative purposes. The flat cut veneers had no noticeable cutting checks.

There is no special standard for compression tests for veneers. For the experiments, round shaped speci- mens were used. The round shape ensured that the same amount of cut fibres was always stressed. The thickness of the specimens corresponded to the veneer thickness. Stress was raised uniformly till $34 \mathrm{~N} / \mathrm{mm}^{2}$, in order to reach the plastic range of the material and after that unloaded immediately. The strain measurement was conducted with the testing machine corrected with a machine stiffness correction.

30 specimens with a diameter of $15 \mathrm{~mm}$ and a thickness of approximately $0.5 \mathrm{~mm}$ were tested. The production of veneers results in a direction between radial and tangential direction as thickness direction. So the veneers were stressed perpendicularly to the fibre, but not exactly in radial or tangential direction.

In order to avoid a non-uniform pressure in the case of uneven, inclined running specimen surfaces, the upper part of the testing device was designed to be movable. The lower part of the testing device was designed to be fixed.

For investigating the deformation behaviour of the veneer, different specimens were pressured under a light microscope. To that end a mini precision compression device was used, which was stepwise closed manually. Images were taken at different pressure levels and used to exactly determine the actual thickness of the specimen. Thus it was possible to determine the strain and relate it to the stress-strain curves obtained from the testing machine.

The specimens were conditioned to $21^{\circ} \mathrm{C}$ and $65 \%$ relative humidity and tested under the same conditions.

\section{RESULTS AND DISCUSSION} 3. REZULTATI I RASPRAVA

Figure 2 shows a typical stress-strain curve of a veneer compression test. After the initial flat slope of stress up to approximately $0.5 \mathrm{~N} / \mathrm{mm}^{2}$ and $10 \%$ strain (range I), the stress rises steeply. This range II is approximately located between 10 and $20 \%$ strain. In the range III, the slope truncates clearly, but without a distinctive plateau. With a strain of approximately $25 \%$, the slope becomes steeper again.

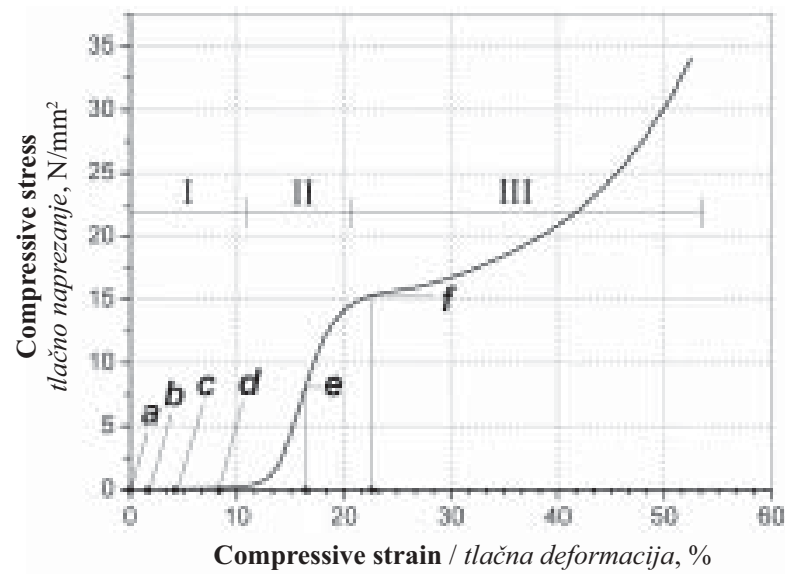

Figure 2 Stress-strain curve of a beech veneer compressive test

Slika 2. Krivulja naprezanja-deformacija za kompresijski test bukova furnira 
The letters $(\mathrm{a}-\mathrm{f})$ within Figure 2 are the letters of the microscopic images in Figure 3, related to the stress-strain curve.

Figure $3(\mathrm{a}-\mathrm{f})$ shows the microscopic images related to the diagram in Figure 2. The borders of the compressive plates and the compression device are marked with a black line, respectively. It can be seen that the compressive plates in Figure $3 \mathrm{~d}$ do not abut on the veneer completely. There is already a strain of $7.8 \%$. Only in Figure $3 \mathrm{e}$ the borders of the compressive plates seem to be in complete contact with veneer. A high strain of $17.1 \%$ can be recognised there. The microscopic images show that there is a difference between macroscopic and microscopic deformation and displacement in case of compressive stress of a veneer in thickness direction. The macroscopic deformation means the straightening of the waved veneer. The thin veneers are not absolutely plane, but slightly warped. This kind of deformation is measured during the compressive test as elastic strain and occurs at a very low stress level. This first range generates the straight line in the stress-strain diagram with a very low slope and a relatively high strain (range I in Figure 2). In the following range II of the diagram, elastic and plastic strains are supposedly parallel. This conclusion can be drawn from the microscopic studies. The measurements of the alternation in thickness in the microscopic range showed that plastic strains occur during strains at a relatively low level (for example after stressing with $2.5 \%$ strain, a permanent elongation of $0.5 \%$ could be measured). However the values of permanent elongation are in a range of 1 to $2 \mu \mathrm{m}$, a dimension that cannot be detected with a testing machine. These values are in the range of the noise and cannot be measured as plastic elongation. Although this plastic elongation can be measured using the microscope, no deformed cellular tissue can be detected at 100-fold magnification. The material seems not to have suffered any damage
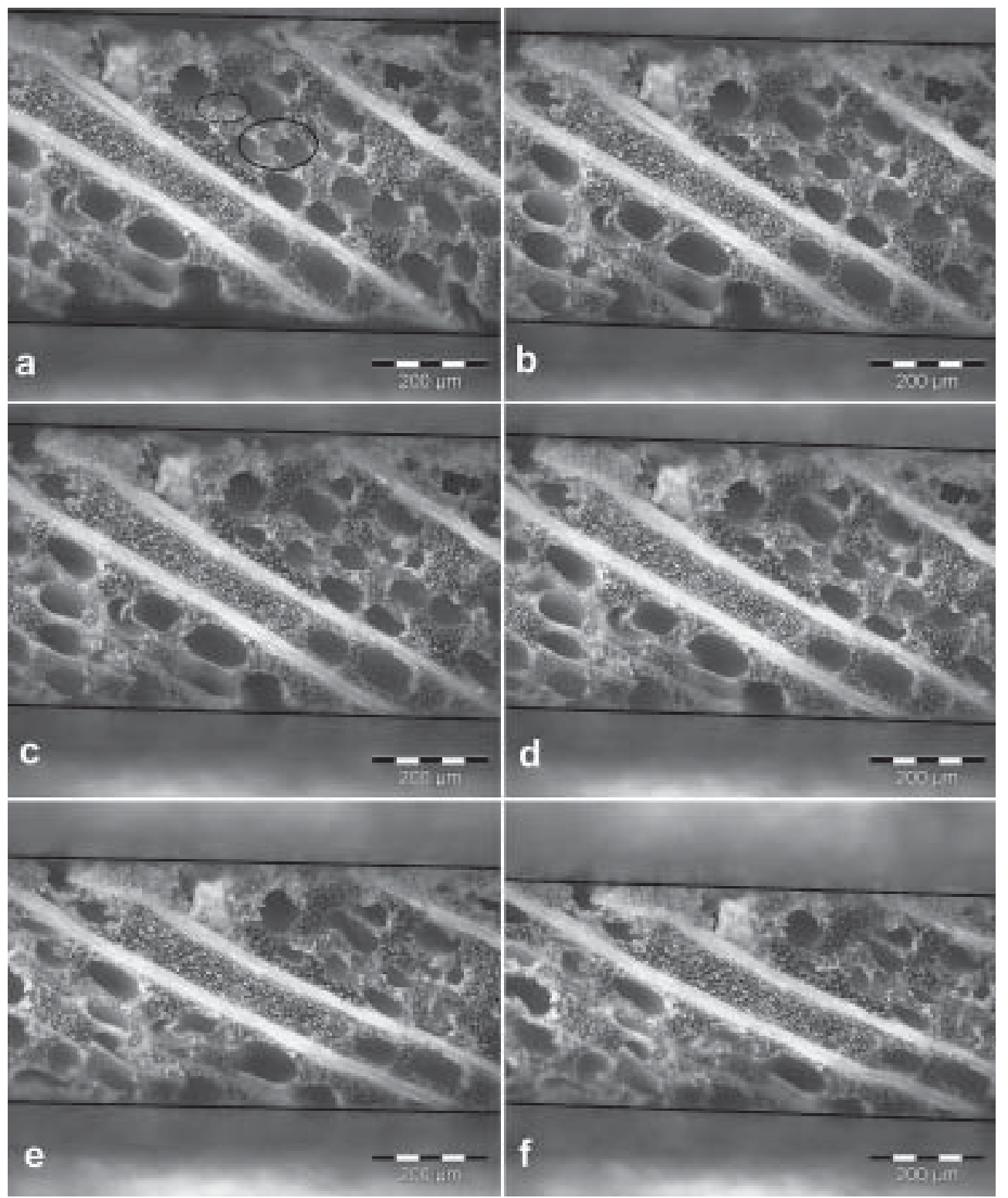

Figure 3 Microscopic images with different compressive strain situations: a) without stress, b) $1.9 \%$ strain, c) $4.9 \%$ strain, d) $7.8 \%$ strain, e) $17.1 \%$ strain, f) $23.1 \%$ strain

Slika 3. Mikroskopske slike s različitim veličinama deformacije zbog naprezanja: a) bez naprezanja, b) deformacija 1,9\%, c) deformacija $4,9 \%$, d) deformacija $7,8 \%$, e) deformacija $17,1 \%$, f) deformacija $23,1 \%$ 


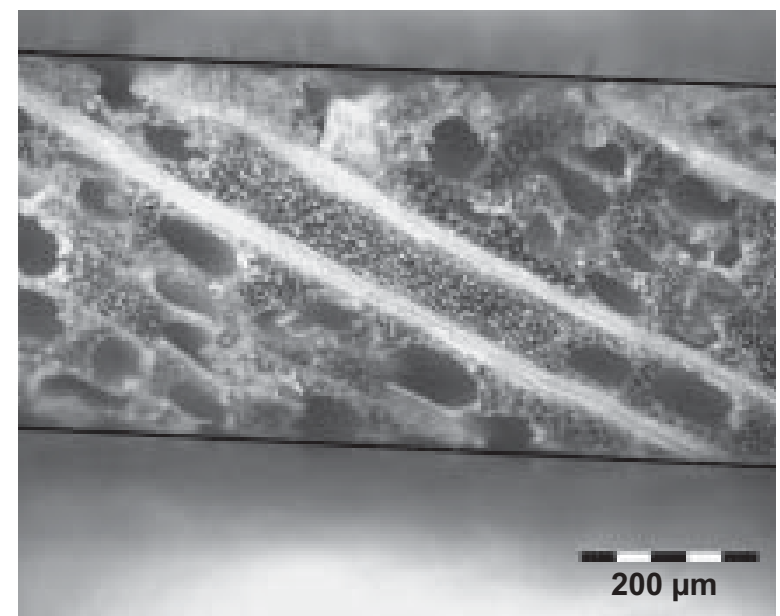

Figure 4 Specimen after the compressive test in unstressed status

Slika 4. Uzorak nakon kompresijskog testa u stanju bez naprezanja

due to the stress. Cracks and failures in the cell walls, at the rays or between the cells can already be detected before the beginning of stress (see remarked areas in Figure 3a). However, it is not verifiable if the failures are caused by the specimen preparation or the production of the veneer. Nevertheless, it can be supposed that the plastic strain portion occurs due to existing tissue damages or due to the displacement of cells or cell lines against each other. Therefore 1 to $2 \mu \mathrm{m}$ displacement and elongation are possible, respectively.

The range III in Figure 2 is represented by the microscopic image in Figure 3f. Plastic deformations occur there. A typical distinctive stress plateau has not been established for all veneer specimens. Probably there are not enough large cell lumens that can be compressed. The few cavities available are compressed without generating a large amount of strain with constant stress. Then the stress rises strongly.

Figure 4 shows the specimen after the test in unstressed status. The permanent deformations of the cell tissue can be seen clearly.

\section{CONCLUSIONS \\ 4. ZAKLJUČCl}

The stress-strain behaviour from veneers in thickness direction under compressive stress differs from that of other known stress-strain curves of wood. Due to the waved form of the veneer sheets and specimens, a considerable part of the strain occurs by straightening the veneer at a relatively low stress level. A distinctive stress plateau has not been established.

The compressive stress, applied during the coating process, amounts to 1 to $2 \mathrm{MPa}$. The veneer can endure this stress without substantial damages.

\section{Acknowledgements - Zahvala}

The tests and results of this publication have been financially supported by the Federal Ministry of Economics and Labour through the German Federation of Industrial Cooperative Research Associations "Otto von Guericke" (AiF 15804 BR/1).

\section{REFERENCES}

5. LITERATURA

1. Ellis, S.; Steiner, P., 2002: The behaviour of five wood species in compression. IAWA Journal 23 (2): 201-211.

2. Dwianto, W.; Norimoto, M.; Morooka, T.; Tanaka, F.; Inoue, M.; Liu, Y., 1998: Radial compression of sugi wood (Cryptomeria japonica D. Don). Holz Roh. Werkst. 56: 403-411, http://dx.doi.org/10.1007/s001070050342.

3. Gibson, L. J.; Ashby, M. F., 1997: Cellular solids, structure and properties. Cambrigde University Press, Cambridge.

4. Inoue, M.; Sekino, N.; Morooka, T.; Rowell, R.; Norimoto, M., 2008: Fixation of compressive deformation in wood by pre-steaming. J Trop. Forest Sci. (20) 4:273281.

5. Morsing, N., 2000: Densification of wood the influence of hygrothermal treatment on compression of beech perpendicular to the grain. Danmarks Tekniske Universitet Kgs. Lyngby.

6. Shams, M. I.; Yano, H., 2004: Compressive deformation of wood impregnated with low molecular weight phenol formaldehyde (PF) resin II: Effects of pressing pressure and pressure holding. J. Wood Sci. 50:337-342.

7. Tabarsa, T.; Chui, Y. H., 2001: Characterizing microscopic behavior of wood under transverse compression. Part II. Effect of species and loading direction. Wood Fiber Sci 33:223-232.

\section{Corresponding address:}

BEATE BUCHELT, Dipl. Ing.

Technische Universität Dresden

Institute of Wood and Paper Technology

01062 Dresden, GERMANY

e-mail: beate.buchelt@tu-dresden.de 